
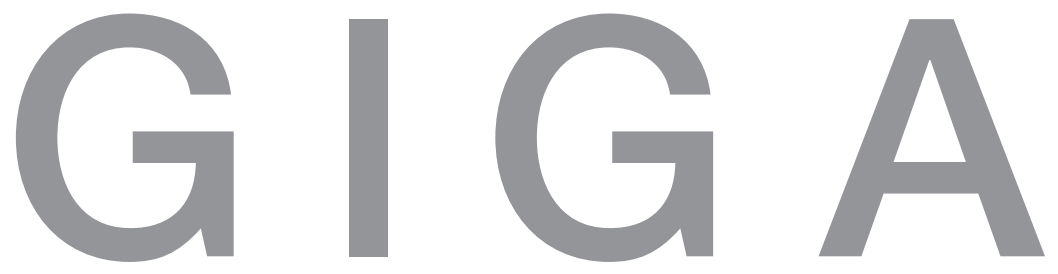

Working

German

Institute of Global and Area Studies Papers

Leibniz-Institut für Globale und Regionale Studien

GIGA Research Programme:

Transformation in the Process of Globalisation

Power, Governance, and Ideas in Chile's Free Trade Agreement Policy

Leslie Wehner

No 102

May 2009 


\section{GIGA Working Papers}

Edited by the

GIGA German Institute of Global and Area Studies

Leibniz-Institut für Globale und Regionale Studien

The GIGA Working Papers series serves to disseminate the research results of work in progress prior to publication in order to encourage the exchange of ideas and academic debate. An objective of the series is to get the findings out quickly, even if the presentations are less than fully polished. Inclusion of a paper in the GIGA Working Papers series does not constitute publication and should not limit publication in any other venue. Copyright remains with the authors. When working papers are eventually accepted by or published in a journal or book, the correct citation reference and, if possible, the corresponding link will then be included on the GIGA Working Papers website at <www.giga-hamburg.de/ workingpapers>.

GIGA research unit responsible for this issue:

Research Programme: "Transformation in the Process of Globalisation"

Editor of the GIGA Working Papers series: Martin Beck <beck@giga-hamburg.de>

Copyright for this issue: (C) Leslie Wehner

English copy editor: Melissa Nelson

Editorial assistant and production: Vera Rathje

All GIGA Working Papers are available online and free of charge on the website $<$ www. giga-hamburg.de/workingpapers $>$. They can also be ordered in print. For production and mailing a cover fee of $€ 5$ is charged. For orders or any requests please contact:

E-mail: workingpapers@giga-hamburg.de

Phone: ++49 (0)40 - 42825 - 548

The GIGA German Institute of Global and Area Studies cannot be held responsible for errors or any consequences arising from the use of information contained in this Working Paper; the views and opinions expressed are solely those of the author or authors and do not necessarily reflect those of the Institute.

GIGA German Institute of Global and Area Studies

Leibniz-Institut für Globale und Regionale Studien

Neuer Jungfernstieg 21

20354 Hamburg

Germany

E-mail: info@giga-hamburg.de

Website: www.giga-hamburg.de 
GIGA WP 102/2009

\title{
Power, Governance, and Ideas in Chile's Free Trade Agreement Policy
}

\begin{abstract}
Why is Chile following such a proactive FTA policy and at the same time promoting the benefits of these type of agreements to other Latin American countries? There is a predominance of economic explanations to analyze why countries pursue an active FTA policy. Yet within an FTA policy, understood as an essential component of a country's foreign policy, strategic and ideational goals are also important. Without downgrading economic explanations, I argue in this article that Chile's proactive FTA policy can also be understood using variables from "traditional" international relations such as power, governance, and ideas. A framework based on such political-economic strategic issues and value-based ideas provides a better understanding of the country's motivations in implementing such a proactive FTA policy.
\end{abstract}

Keywords: FTAs, status, soft balancing, economic dependence, governance, ideas, Chile

\section{Leslie Wehner}

is a political scientist, a PhD student at the GIGA Institute of Latin American Studies, and a DAAD scholar.

Contact: wehner@giga-hamburg.de

Website: http://staff.giga-hamburg.de/wehner 


\section{Zusammenfassung}

\section{Macht, Governance und Ideen in Chiles Freihandelspolitik}

Was sind die Gründe für Chiles derartig aktive Freihandelspolitik und dafür, dass Chile die Vorteile dieser Art von Abkommen gleichzeitig auch anderen lateinamerikanischen Staaten anpreist? Zur Erklärung, warum Länder eine aktive Freihandelspolitik verfolgen, werden überwiegend ökonomische Gründe aufgeführt. Doch bei einer aktiven Freihandelspolitik, die als wichtiger Bestandteil der Außenpolitik angesehen wird, müssen auch strategische und ideelle Ziele Berücksichtigung finden. Ohne die ökonomischen Erklärungen abzuwerten, wird in diesem Beitrag die Auffassung vertreten, dass Chiles aktive Freihandelspolitik auch als Rückgriff auf „traditionelle“ Variablen der internationalen Beziehungen wie Macht, Governance und Ideen verstanden werden kann. Eine Darstellung der politisch-ökonomischen Strategiefragen und der ideellen Aspekte lässt die Beweggründe dieses Landes für eine solch aktive Freihandelspolitik einfacher nachvollziehen. 


\title{
Power, Governance, and Ideas \\ in Chile's Free Trade Agreement Policy
}

\author{
Leslie Wehner
}

\section{Article Outline}

1 Introduction

2 Analytical Framework

3 The Power-based Goals of Chile's FTAs

4 Chile's FTAs as Governance Institutions

5 Ideational Aspects in Chile's FTA Policy

6 Conclusion

\section{Introduction}

Chile is the most active country in negotiating Free Trade Agreements (FTAs) in the global economic world. ${ }^{1}$ The country enjoys expertise on how to negotiate and build these commercial accords as it has signed around 19 FTAs including the Economic Partnership Agreements (EPAs) (see Table 1). ${ }^{2}$ Chile's FTA approach is a long-term policy as its trade negotiations have not been stalled by unfavorable external economic conditions such as the Asian and the sub-prime crises. Moreover, Chile is always ready and willing to share its negotiating experience with other Latin American countries that may become direct economic competitors, such as Peru, Costa Rica, Colombia and Panama. It even supports these countries in joining extant FTAs such as the P4 and economic forums such as APEC, which are also used as arenas to monitor possible FTAs (Furche 2008).

1 An FTA has the purpose of securing commercial preferential treatment between signatory countries vis-à-vis third countries that are excluded from such an agreement (Corning 2007: 45).

2 EPAs are FTAs that include other issues such as economic cooperation and development. Sometimes they include non-trade-related issues. Complementary Agreements (CA) and Partial Trade Agreements (PTA) are not considered FTAs because of their limited scope. These latter two types are also included in Table 1. 
Table 1: Chile's FTAs

\begin{tabular}{|c|c|c|c|}
\hline Country / regional bloc & Type of accord & Date of signature & Status \\
\hline P4 (I) & EPA & 18.07.2005 & implemented (08.11.2006) \\
\hline EU (II) & EPA & 18.11.2002 & implemented (01.02.2003) \\
\hline Japan & EPA & 27.03.2007 & implemented (03.09.2007) \\
\hline Canada & FTA & 05.12 .1996 & implemented (05.07.1997) \\
\hline South Korea & FTA & 15.02 .2003 & implemented (01.04.2004) \\
\hline China & FTA & 18.11 .2005 & implemented (01.10.2006) \\
\hline Costa Rica (III) & FTA & 18.10 .1999 & bilateral protocol implemented (14.02.2002) \\
\hline El Salvador (III) & FTA & 18.10 .1999 & bilateral protocol implemented (03.06.2002) \\
\hline Honduras (III) & FTA & 18.10 .1999 & bilateral protocol implemented (18.07.2008) \\
\hline USA & FTA & 06.06 .2003 & implemented (01.01.2004) \\
\hline Mexico & FTA & 17.04.1998 & implemented (01.08.1999) \\
\hline EFTA (IV) & FTA & 26.06 .2003 & implemented (01.12.2004) \\
\hline Panama & FTA & 27.06 .2006 & implemented (07.03.2008) \\
\hline Peru & FTA & 22.08 .2006 & implemented (01.03.2009) \\
\hline Colombia & FTA & 27.11 .2006 & implemented $(08 / 05 / 2009)$ \\
\hline Australia & FTA & 30.07 .2008 & implemented (06/03/2009) \\
\hline Guatemala (III) & FTA & 18.10 .1999 & bilateral protocol on ratification process \\
\hline Nicaragua (III) & FTA & 18.10.1999 & bilateral protocol on negotiation \\
\hline Turkey & FTA & $\mathrm{N} / \mathrm{A}$ & concluded in agreement (20.03.2009) \\
\hline Malaysia & FTA & N/A & under negotiation \\
\hline Vietnam & FTA & $\mathrm{N} / \mathrm{A}$ & under negotiation \\
\hline India & PTA & 08.03 .2006 & implemented (17.08.2008) \\
\hline Cuba & PTA & $21.08 .1998(\mathrm{~V})$ & implemented (28.08.2008) \\
\hline Ecuador & CA & 20.12.1994 & implemented (01.01.1995) \\
\hline Mercosur (VI) & CA & 25.06 .1996 & implemented (01.10.1996) \\
\hline Bolivia & CA & 06.04 .1993 & implemented (07.07.1993) \\
\hline Venezuela & CA & 02.04 .1993 & implemented (01.07.1993) \\
\hline
\end{tabular}

Notes: I New Zealand, Singapore, Chile and Brunei are the P4 members.

II The EU has 27 member states.

III Chile negotiated a common FTA framework with Central America and then bilateral protocols with each country. It is still negotiating this protocol with Nicaragua.

IV Iceland, Liechtenstein, Norway and Switzerland constitute the European Free Trade Association (EFTA).

$\mathrm{V}$ This is the date on which Cuba and Chile concluded the negotiation.

VI Brazil, Argentina, Paraguay and Uruguay are full members.

Source: Direcon-Chile: www.direcon.cl.

Despite the evident rush of this Latin American country to finalize FTAs, there are no clear explanations for its pursuit of such a proactive policy beyond the pure economic logic of maximizing the welfare of consumers and the net gains of producers. Why is Chile following such a proactive FTA policy and at the same time promoting the benefits of these type of agreements to other Latin American countries? If these questions are analyzed using an economic logic, the answers are rather obvious: 
- Chile negotiates FTAs to create trade and to impede its diminution by third parties possibly leaving Chile out of these accords or out of regional economic groupings (Viner 1950, Baldwin 2006: 1467-1468).

- Chile has the goal of achieving a high number of FTAs in order to attract foreign direct investment (FDI) (Gerber 2000).

- In a North-South context, Chile has signed FTAs with the main economic centers of the world in order to increase the export volumes of its most competitive products, which are mainly commodities.

- In a South-South context, Chile's FTA policy has the goal of promoting the export of products with greater added value (industrial goods), which are usually produced by small and medium-sized enterprises (SMEs) (Rosales 2008).

- Chile shares its negotiating experience and the benefits of an FTA policy with other Latin American countries because its production chain has expanded to other countries on the continent, along with growing capital investments coming from Chile.

This utility-maximizing rationale is one of the main forces for jumping onto this wave of FTAs. However, economic institutions such as FTAs do not exist in a vacuum. They also reflect political interests and the values of states, as well as the ambitions of middle-sized or small powers to influence and shape, at the least, their regional setting. In other words, pure economic explanations do not capture the political dimension of elaborating and conducting an FTA policy. An FTA policy is also a constitutive part of the foreign policy of a country, and as such it may be used to achieve strategic goals and promote values which are part of the world and regional views of a state.

Therefore, I argue in this paper that Chile is also seeking to realize its foreign policy goals through FTAs, following a strategic political-economic rationale as well as its value-based ideas. ${ }^{3}$ First, Chile is trying to balance the power of other states or regional blocs in Latin America, to reduce the asymmetric economic dependence on global powers and the potential political influence these powers might exert, and to achieve a greater international reputation. Second, Chile is seeking to implement more specific rules of the game as well as ad hoc mechanisms of global economic governance that reflect the specificity of its economic context and reality. Finally, Chile is seeking to shape how the construction of economic integration should be in Latin America by promoting its own conception of the market as welfare enhancer. This initiative not only helps other countries on the continent to "lock-in" the model internationally but it also acts as a self-validating mechanism for Chile's own pattern of development. Thus, if the external relations of a small country are usually constituted around

3 In this regard, states use economic issues strategically. Moreover, value-based ideas on patterns of development as well as economic issues and traditional issues of foreign policy overlap and mix in an international trade agenda. 
power concerns, the need for better and context-based governance mechanisms, and value-based ideas, then these may also be driving forces in pursuing such a proactive FTA policy.

This article is structured in the following way: First, I introduce the analytical framework, which helps to explain why Chile is so proactive in formulating an FTA policy. Here I rely on elements of neorealism and institutionalism to outline the power-based goals that Chile seeks to achieve through its FTA policy. I then present the theoretical aspects of governance, taken from institutionalism, that help to analyze Chile's FTAs as governance institutions. At the end of this section I introduce a constructivist theoretical conception of the FTA as a reflection of an intersubjective societal understanding. Rather than contributing to the theoretical debate, this article seeks to solve an empirically grounded puzzle by using elements of the three grand theories of international relations in a rather eclectic way. ${ }^{4}$ Second, I assess Chile's FTA policy as a means to achieve strategic political-economic goals according to power-based explanations. Third, I analyze another political-economic strategic goal of Chile's FTA policy, which is to have rules for global economic governance that represent the specificity of the political-economic reality of Chile. Here I focus on the mechanisms for managing investment matters as an illustrative case (investment chapters). Fourth, I assess whether and to what extent ideational aspects are constitutive parts of the country's FTA policy as well as why Chile is so keen to share its negotiating experience and to invite other countries to join extant FTAs. Here I use some data taken from opinion poll studies, which are supplemented by an analysis of the speeches and public statements of key representatives of civil society as well as the government. The conclusion assesses which of these three forces-power, governance, or ideas-has more power to explain the FTA policy of this country, or whether they have to be seen as complementary approaches.

\section{Analytical Framework}

\subsection{A Power-based Explanation}

According to neorealism, power is expressed in the material capabilities states have to achieve their foreign policy goals. States usually exercise power based on their material capabilities and on their relative power position (Rose 1998). The economic sphere is only another dimension in which power is displayed and sought (Gilpin 1987, 2001, Grieco 1990). Following a relational conception of power, a state like Chile may be categorized as a middle-sized power that uses its power assets to influence and shape the course of external relations within its region. And on the global level, it may act as a small power by trying to reduce the asymmetrical economic dependence on, and the potential political influence com-

4 The benefits of using analytical eclecticism have mainly been introduced, and developed by Peter Katzenstein in his various publications: see especially P. Katzenstein and S. Rudra (2004). 
ing from, one or a few economic power centers. However, influencing other Latin American countries and balancing the power of countries or regional groupings within and outside Latin America is not conducted in hard terms within an FTA policy.

In this regard, institutionalism highlights the fact that the economic world is interdependent, something which makes the use of hard power a costly business. In the interdependent world, states instead use soft balancing (Fortman et al. 2004: 370) or create a new set of institutions as a form of institutional balancing (He 2008: 492). Soft power is thus present in the economic sphere (Nye 2007: 165-167). In trade wars it is likely that states will use hard and economic power such as threats and sanctions, but within FTAs countries place a stronger emphasis on framing the FTA as a win-win situation, highlighting elements of economic and soft power. Thus, having multiple FTAs may act as a soft mechanism for influencing other countries, as an institutional balancing mechanism, and as the means to diffuse the politicaleconomic weight of the most important economic powers of the world.

\subsection{A Governance-based Explanation}

Power-based goals are only one dimension of the strategic goals a state seeks to achieve when it pursues an FTA policy. Institutions, such as these trade accords, are also the manifestation and the result of cooperative behavior between states. Cooperation is a strategic choice amongst states (Keohane 2005). Imposing a desired policy or an interest-based behavior is not the way middle-sized or small powers act within the international system. It is also certainly not the case for a regional and hegemonic power when it comes to FTAs. On the contrary, launching an FTA negotiation is based on attracting and convincing the counterpart(s) that a trade agreement will not only boost their economic exchange but also reduce the transaction costs of their political-economic relationship.

Establishing institutions such as FTAs is a way to face the uncertainty posed by the even more complex situation of the WTO trade-based regime, although FTAs do not necessarily oppose the essence of the rules of this multilateral institution. Having FTAs is thus a way to deal with the challenges of economic globalization. Economic globalization has created a need amongst states to design better rule-based mechanisms for managing the world economy as the movement of capital, goods, and services increases (Schirm 2004: 3-7). States have been able to develop a sophisticated and complex rule-making system on multiple levels covering a broad set of issue areas, although this system is still far from being flawless as the recent financial crises show.

The global economic governance system as a whole is composed of multilateral institutions such as the WTO and the IMF; interregional institutions such as EU-Mercosur and APEC; regional institutions such as Mercosur, NAFTA, and the EU; sub-regional institutions such as the Euro regions; and the bilateral relations between states (Loewen 2006). Yet all these 
levels are intertwined. Thus, some rules that originate on one level may be implemented completely or partially, as well as adapted, by actors or institutions on other levels in both a top-down and a bottom-up direction. This flow of rules may also be horizontal, that is, from institutions or actors at the same level of governance, for example, from the IMF to the WTO or from the EU to Mercosur (Woolcock 2006).

Therefore, FTAs represent only a small but nevertheless important fraction of the rule making needed to manage the economic world. One of the purposes of the FTAs as governance mechanisms is to provide certainty to the economic actors and the states in their relationships. Another is to design rules that reflect the political-economic reality of each country as well as the specificity of the economic relation of the parties involved in an FTA negotiation.

\subsection{An Ideational-based Contextual Understanding}

Ideas play a strong role in the way the policy preferences of state actors are elaborated and implemented. Ideational forces take the form of worldviews, principled beliefs, and causal beliefs in international relations, although these are intertwined and mutually constitutive (Goldstein and Keohane 1993). International actions are not only based on a cost-benefit analysis, they are also the manifestation of an intersubjective process of mutual understanding (March and Olsen 1998). Prevalent ideational aspects that underlie societal projects are path dependent. Thus, the meaning of such prevailing societal ideas has to be shared by a majority of actors (Schirm 2004). If a society shares the value-based idea that an open market economy enhances the welfare of its society in the long run, then this mutual understanding may facilitate the undertaking of a proactive and intense FTA policy by leaders and states. This does not mean there are not other ideational aspects in a society trying to contest and displace prevailing ideas in the long run (Schirm 2008: 5).

As part of the international actions of a country, an FTA policy may also be the reflection of the prevailing idea that an open market economy improves the welfare of citizens. ${ }^{5}$ However, prevailing ideas and values are usually not the same for each country, although some may share certain notions and the underlying value-based idea of an economic model. The impact of ideational aspects from middle-sized or small countries on others is rather diffuse in the case of countries that are outside a region as interstate socialization is more sporadic. In these cases the trade agenda is instead interest driven, although it serves the purpose of reinforcing value-based ideas at the domestic level. Ideational aspects may be more concrete and have a more major impact when countries are part of the same region, have a similar culture, and share common past experiences. Here interests and ideas reinforce each other

5 I also use the ideational aspect "market as welfare enhancer" in this section as it also reflects the idea that an open economy or a market-driven economy increases the welfare of citizens in the long run. 
when there are common regional views among actors on how and under what pillars political-economic integration should be founded and sustained.

In addition, in a regional setting the same principles may also be more intensively contested by other states that share the view that strong state intervention is the path to socioeconomic development. This ideational aspect may also impact the way these actors conceive of and promote regional integration. In other words, competing or complementary views on what integration "should look like" are not only interest-based but also idea-based. Thus, prevailing societal ideas facilitate or constrain the external relations of a country and form the regional views of a country; these may be accepted and shared by some state actors within a geographical region and contested by others.

\section{The Power-based Goals of Chile's FTAs}

One of the main foreign policy goals of Chile once the transition to democracy started in 1990 was its reacceptance in the international system. To achieve this, Chile opted to give priority to the use of economic integration. Internally, political and economic elites saw economic integration as the least conflictive area on which to build up a consistent foreign policy for the future since it produced unity in the political parties represented in congress from the Right to the Left. Externally, Chile's first democratic governments also perceived that other countries in Latin America and in the world would find Chile's economic integration model easy to accept. Most of the Latin American countries were also converting to market economies, and the acceptance of this way of reentering the international arena was also guaranteed at the global level as the major economic powers such as the US and the EU were the main promoters of economic integration.

Not only does the government of Chile want to satisfy its endogenous economic actors with its FTA policy, but it also wants to achieve an international reputation that allows it to influence the process of integration on the Latin American continent (Morande 2003: 252-253). “FTA talks can be used as a tool to improve countries' status and image by allowing them, on the one hand, to display 'benign leadership' through collaborative economic projects" (Solis and Katada 2008: 249).

Chile sees the achievement of an FTA with the US in 2003 as a source of pride and success as it has become a sort of "quality stamp" for the Chilean economic model, with a direct effect on the image and international status of the country. As then president Ricardo Lagos (20002004) said with regard to the country's FTA with the US,

Today Chile is part of the world. Our small and far away country that in previous periods was isolated and marginalized becomes today a first class partner of the main hubs of the world economy. Months ago it was with Europe, weeks ago it was with 
South Korea and today with the United States of America. All this happened in one year. ${ }^{6}$ (quoted in Fuentes 2006: 120)

Influence on the continent's integration process cannot be exerted by the size of the Chilean market as such, so influencing others is based on the strategy of attracting possible negotiation counterparts by promoting the success of Chile's economic reforms, its good performance in the global economy, and its know-how in building these agreements.

Chile depends to a large extent on commodity exports, so it tends to adopt a defensive position in the world economy with regard to global hubs. On the one hand, it wants to have access to relevant economic markets for economic reasons, but on the other hand, it does not want to be too heavily dependent on one of them, for both economic (vulnerability) and political reasons (political influence) (Ulloa Urrutia 2003: 25, Wesley 2008: 223). This is especially the case for the country's relationship with the US. "The dependence on one market also produces volatility regarding prices and constrains the political and economic independence of a country" (López Giral 2006: 717). ${ }^{7}$ While Chile sought to have an FTA with the US, it also wants to reduce the asymmetric economic dependence on this market by pursuing previous, parallel, and subsequent FTA negotiations with other industrialized countries or regions such as the EU (2002), Korea (2003), China (2006), and Japan (2007). ${ }^{8}$ Although Chile signed its FTA with the US in 2003, after those with Korea and the EU, it was always Chile's main priority to negotiate an FTA with the US, either by trying to join NAFTA or by negotiating a bilateral FTA (Verdugo 2005: 160). Yet the dynamics of domestic politics in the US impeded the achievement of this goal in the 1990s.

With this strategy of negotiating with commercial hubs of the world economy and not generating too strong a dependency on one or two of those economic centers, Chile has also put special effort into achieving commercial accords with the Latin American countries as a way to exert a certain influence over the process of integration in the region. It has negotiated accords with Mercosur (1996), Mexico (1998), the Central American countries (1999), Colombia (2006), Peru (2006), and Panama (2008). Based on its strategic need to not becoming a spoke of the integration process in the global economy, Chile has become a hub on the Latin American continent (Rosales 2008, Zechner 2002: 124). This game of hubs and spokes may favor the former in economic exchange, since the hubs can freely trade with every spoke but the spokes will face limitations on trading with other spokes due to the lack of accords between them (Wonnacott 1996). Therefore, as a hub Chile may have, at least potentially, the tools to exert

\footnotetext{
Author's translation.

Author's translation.

Chile has been rather successful in reducing this asymmetric economic dependence by diversifying its trade relations. In the early 1990s Chile's main market for exports was the US, followed by Japan; currently it is China (15.2\%) and then the US (13.1\%). If the EU is taken as a whole, then Chile's exports to this region are higher than those to the two previous markets (21.5\%) (Direcon 2008: 12, Silva 2001: 15).
} 
a certain degree of influence in the way flows of products and services are distributed on the Latin American continent. Yet being a hub is not only about controlling commercial flows; it is also about gaining political leverage over the integration schemes and over how this integration should be conducted (Smith 2001: 49).

The FTA policy of a country can also have an effect on the way border issues are treated (McDonald 2004). Chile negotiated an FTA with Peru which is based on a previous Complementary Agreement (1998). It also has a low-scope trade accords with Bolivia (1993), with which maritime and territorial disputes exist. These conflictive relations are the consequence of the Nitrate War in 1879-1884 and the resulting peace and border accords with Peru in 1929 and Bolivia in 1904. As consequence of this war, Bolivia lost access to the sea, which has been the main issue in its foreign policy towards Chile since then. Peru and Chile also have ongoing disputes over the territorial and maritime borders (Valdivieso 2007). Chile is the status quo country with regard to these issues. In the first years of democracy, Chile did not know much about the intentions, interests, and possible reactions of its neighboring countries if border issues were the only item on their foreign policy agendas. Neither did Peru nor Bolivia know about the possible reactions of Chile if the respective bilateral relations were to be coupled with security issues.

In accordance with the commercial peace literature, which holds that commercial relations increase the cost of using military means to solve border issues (Oneal 1999, Gartzke/Li/ Boehemer 2001), Chile's FTA policy has thus helped to reduce the focus on security in Chile's relations with its neighbor countries. After achieving complementary trade agreements with Bolivia and Peru, and an FTA with Peru (2006), the option of using military means to tackle the border discrepancies was seen as nonviable in the medium and long term because of the decline in trade relations and in the economic welfare of each state that would result. As José Miguel Inzulsa, the minister of foreign affairs under then president Eduardo Frei (1994-1998), said, "the economic complementation and integration agreements which we have promoted in recent years, although mainly concerned with trade, can also have implications as regards increasing the security of Chile in our regional environment" (quoted in Saéz and Valdés 1999: 94).

Chile is an associate and not a full member of Mercosur. Even though one of the most convincing justifications for this status is that Chile has a lower tariff rate than that of Mercosur, Chile's government believes that this bloc could undermine the country's independence regarding its foreign policy goals. Moreover, it sees Mercosur as a political arena rather than a global market-driven project, which is what Chile would prefer. Chile thus has an ambivalent position towards this regional grouping. On the one hand, it is committed to its economic growth, but on the other hand, it does not want Mercosur to become a political platform for projects based on state intervention in the economy, or for Venezuela's Bolivarian 
project (Portilla 2006). The skeptical viewpoint on this group is also based on Chile's perceptions that Mercosur's institutions are not efficient enough to deal with the political and economic disputes that have emerged among the member states.

In fact, Chile does not want to step back from Mercosur since it has strong economic ties with it. Instead, Chile is pursuing a soft-balancing strategy as it wants to lessen both its economic dependence on this integration scheme and Mercosur's potential political influence. Therefore, Chile has used the strategy of diversifying its commercial relations by having different FTAs on the continent. It has recently rejoined the Andean Community and it is seeking the convergence of its FTAs with Colombia, Peru and possibly Mexico as a way of balancing the pattern of development based on more state intervention promoted by Mercosur, and especially by Venezuela and Argentina.

By opening new markets and by having FTAs with all the economic powers and developing countries, Chile is increasing its overall external trade dependence. However, it is also reducing both the economic impact and the potential political influence that world powers and regional groupings may exert over it through the diffusing effect that multiple commercial ties produces.

\section{Chile's FTAs as Governance Institutions}

Chile's FTAs are focused not only on the removal of tariffs but also on the management of a diverse array of issue areas such as sanitary and phytosanitary measures, the use of technical barriers to trade, public procurement, normalization measures, trade conflicts, property rights, rules of origin, services and investment, etc. The joint points on these issues are the facilitation of trade in goods and services as well as the creation of conditions which impede discrimination against incoming products and services vis-à-vis national ones. As the minister of foreign affairs Soledad Alvear said in 2005, "These accords allow us to ensure clear rules of the game as well as juridical certainty for the decisions of our exporters and investors" (Verdugo 2005: 165). ${ }^{9}$

Attracting foreign direct investment (FDI) has been one of the key issues in Chile's trade policy and economic growth. Chile's FTAs include investment chapters with the purpose of delineating clear rules to protect and facilitate its own FDI abroad and the incoming investment from the counterpart. ${ }^{10}$ "In general these agreements are designed to give foreign in-

\footnotetext{
Author's translation.

10 In some FTA negotiations Chile and its respective counterparts included the modality of negotiating the chapters over services and investments after the FTA was in force, e.g., with China and the P4. The former negotiation has already been concluded and the new chapters are part of the main FTA. The P4 negotiations on investment and services are ongoing. The US has joined the P4 negotiation process on investment and services as a step towards becoming a member of this accord.
} 
vestors national treatment, to create a most-favored-nation (MFN) form of investment, to end the performance requirements, and to eliminate restrictions on the return of capital and revenues" (Gerber 2000: 48). ${ }^{11}$

The investment matters in Chile's FTAs include different elements taken from multilateral accords that are part of the WTO trade-based regime, such as the Agreement on Traderelated Investment Measures (TRIMs), the General Agreement on Trade in Services (GATS), the Agreement on Subsidies and Countervailing Measures (ASCM), the Agreement on Traderelated Aspects of Intellectual Property Rights (TRIPs) and the Understanding on the Settlement of Disputes (DSU). Chile has also either included elements of or completely adopted its previous Bilateral Investment Treaties (BITs) in some of its FTAs. These BITs are also nested in the WTO rules (Sauvé 2006: 9-28). In other FTAs it has adopted the NAFTA approach on investment (Reiter 2006). Whereas the BITs seek to protect investment, the NAFTA model of FTAs both protects and liberalizes the investment regime in areas and stages that produce de facto discrimination against foreign investors.

The FTAs that completely adopt preexisting BITs are those with Central America (Costa Rica, El Salvador, Honduras, Guatemala, and Nicaragua) and Panama. These FTAs only seek to confirm the duties and rights the respective parties adopted in their previous bilateral BITs (Chapter 10, Chile-Central America FTA, and Chapter 9, Chile-Panama TLC). In the agreements, the different parties include the possibility of broadening the scope of the investment chapter by establishing an open clause that evaluates the BIT's accords with the purpose of improving them and including new issues, for example, those of the NAFTA model (see article 9.2, Chile-Panama FTA text, and article 10.2, Chile-Central America FTA text). However, in the case of Panama there is no timeframe outlined for starting future negotiations over this matter, whereas in the case of Central America the timeframe is the first two years after the FTA came into force.

Negotiating a new common framework on investment with Central America as a whole is not possible since the bilateral protocol with Nicaragua has not yet been concluded. There is still the possibility of negotiating investment issues in a bilateral way with those countries with which the FTA is in force; however, this has not happened. One reason for this is that the flows of FDI between Chile and each of these countries is not high enough, giving the negotiation of these issues a low priority on Chile's external trade agenda. Thus, Chile seems to see keeping the BITs as the most realistic option, because it has ongoing FTA negotiations to which devote time and human resources.

The BITs include rules to give national and most favored nation (MFN) treatment to the counterpart investor, and to allow the free transfer of capital, interests, rents, and utilities as well as the capital obtained in the total or partial selling of an investment. Moreover, these

11 Author's translation. 
BITs with Central America and Panama prohibit the direct or indirect expropriation of an investment in an arbitrary way. This means that if expropriation is necessary, it has to be undertaken on a nondiscriminatory basis; for a public purpose; in accordance with due process of law; and accompanied by prompt, adequate and effective monetary compensation in accordance with market value. In addition, these treaties include specific mechanisms for the settlement of disputes between states as well as between a particular investor and a state (BIT texts for Chile-Costa Rica, Chile-El Salvador, Chile-Panama: articles I-XI).

Those FTAs that follow a NAFTA pattern on investment measures have a broader scope as they are also intended to liberalize each party's investment regimes. These FTAs are those with Canada, the US, Mexico, Colombia, Peru, Australia, Japan, and South Korea. ${ }^{12}$ These FTAs remove the performance requirement, which means that parties cannot impose certain obligations on each other's investments, for example, to produce given level of exports, to achieve a given level of domestic content, or to purchase locally produced goods in the production process or in the delivery of a service. These chapters of the FTAs also state that giving grants and subsidies to foreign investors cannot be subject to the fulfillment of performance requirements. These FTAs also provide national treatment to the foreign investors in the preestablishment phase. Moreover, Chile's NAFTA model for FTAs also removes the nationality requirement for managers and the members of the boards of directors in enterprises that are covered investments. Yet, in the case of the constitution of a board of directors, a signatory party to the agreement may eventually require that a majority or less of a board's members be nationals or residents of the country that receives the investment. This latter is valid to the extent it does not hamper the ability of the investor to exert control over its own investment in any way (Reiter 2006: 220-222, 227-229).

A different case compared to those above is that of the FTA with the EU. The investment chapter in the EU-Chile FTA is a mixture of BITs, and some NAFTA rules. For example, it does not provide a mechanism for dispute settlements between a private investor and a state as the BITs with Central America or the NAFTA-model FTAs do. It does not remove the performance requirements and does not have clauses on expropriation and compensation measures. While this accord provides national treatment, it does not grant MFN treatment. Therefore, the focus of the investment chapter within this FTA lies on granting national treatment in the access, entry, and establishment of foreign investors as well as on allowing the free and rapid transfer of funds and capital movement (see Chile-EU FTA text, Title III Trade in services and establishment: Chapter III establishment, articles 130-134).

Chile's investment provisions in its FTAs are usually negotiated using a negative list approach. This means that the different clauses that deal with liberalization measures-national 
treatment, MFN status, the preestablishment of commitments, and expropriation-do not apply to specific nonconforming measures, which are usually in the annexes of each FTA. For example, the FTA with Canada has a specific nonconforming measure over indigenous populations and related issues (Chile-Canada FTA text, Annex I) ${ }^{13}$, and the FTA with the US has nonconforming measures on cultural issues. Chile cannot increase the level of protection on the nonconforming measures. Yet these measures are subject to ratchet provisions, with the purpose of facilitating a future liberalization of the respective national investment regimes. If either Chile or its counterparts unilaterally decide to liberalize those measures, these new reformed issues will automatically be included in the respective FTAs.

One of the key issues in Chile's FTAs is to maintain the country's right to preserve the stability of its currency system in the event of a crisis. Chile does this through the annexes of its investment chapters on current payments and capital movements. The measures are devoted to "the establishment of restrictions or limitations on current payments and transfers (capital movements) to or from Chile, as well as transactions related to them, such as requiring that deposit, investments or credits from or to a foreign country, be subject to a reserve requirement (encaje)" (Chile-Japan FTA 2007, Annex 8 clause 1). The rationale is to ensure the liquidity of the system, to prevent speculative investment, and to impede capital flight under adverse economic conditions in the national economy. This mechanism is also present in the FTAs with Canada (Annex G-09.1), Mexico (Annex 9-10), South Korea (Annex 10.11), the US (Annex 10-F clause 7), and Japan (Annex 8 clause 1).

Overall, the investment measures in Chile's FTAs are designed for the purpose of attracting more FDI by giving certainty to the respective counterparts on the investment regime that will frame the economic relationship. Although Chile designs and has adopted rules to protect FDI and liberalize the investment regime, it has also sought to maintain the right to protect itself in the event of currency problems. Moreover, it has also excluded sensitive issue areas such as investment in cultural issues and indigenous affairs. The FTAs are flexible "institutions" since they open up the possibility of including new issues in the future if the political and economic context varies. Nevertheless, this flexibility is a one-way street since it only applies to the liberalization of the investment regime. Therefore, FTAs are there to provide certainty through establishing rule-based mechanisms to deal with the growing movement of goods, capital and services as consequence of economic globalization.

12 These FTAs also protect the respective investments as the BITs do, yet the former have a broader scope as they include new issues. Here I will only focus on the new issues included in the FTAs that follow a NAFTA or a NAFTA-improved model since the other were generally covered in the BITs.

13 This is also the case for the FTAs with Mexico, Central America, US, EU, South Korea, and EFTA. 


\section{Ideational Aspects in Chile's FTA Policy}

Chile's FTA policy and its keenness to share its FTA experience may be the consequence of a long-term socialization process and of an intersubjective understanding within Chilean society that has cemented the ideational aspect "market as welfare enhancer." Internally, the contextual situation of Chilean society is more oriented towards a conception of individual responsibility vis-à-vis a societal pattern of collective and shared responsibility that underlies solidarity projects, as in the models of welfare states such as those in Scandinavia or continental Europe. ${ }^{14}$ A survey by the Chilean Work and Equity Commission ${ }^{15}$ (2008: 32-33) shows that the main reasons for economic success are seen to be the consequence of individual factors (50 percent) such as self-initiative ( 24 percent) and self-responsibility and hard work (26 percent); external factors (27 percent) such as educational level (24 percent) and state economic support ( 3 percent); and family factors such as inherited money (10 percent) and family social contacts (12 percent). Only 3 percent of the population emphasized the role of the state as the main driver of economic success. These tendencies were confirmed when respondents were asked about the main reasons for being poor: answers concentrate mainly on individual factors (51 percent), external factors (33 percent), and family factors (16 percent). Only 8 percent of people believe that poverty is due to the lack of economic support from the state.

In a survey conducted by the Centro de Estudios Públicos (CEP) (May 2008: 59, 61) in which respondents were asked to place themselves on a scale of 1 (the responsibility for the means of economic support lies with the state) to 10 (the responsibility for the means of economic supports lies with the individual), the average is 6.73. It is also interesting to mention the fact that on a scale of 1 to 10 the average is 6.55: individual effort should be valorized and further stimulated (number 10 of the scale), even though this stimulation and valorization of individual effort may substantially affect the income distribution in the Chilean society (number 1 of the scale).

The Latinobarometro (2008: 40) presents some mixed results on questions similar to those of the CEP poll. Those surveyed were asked to answer on a scale of 1 to 10 whether the state ( 1 of the scale) or the market ( 10 of the scale) is responsible for solving society's problems. The average for all respondents is 4.1. This may be interpreted to mean that the role of state is gaining more popularity amongst Chileans; however, the questions do not specify which economic problems the pollsters are referring to. Nevertheless, the Latinobarometro (2007: 23) also includes the question of whether it is fair to pay a better wage to a worker who is more efficient vis-à-vis others who perform the same duties but are less efficient; 57 percent answered that it is fair to pay more to the efficient workers. The same survey (2007: 32) also

14 On the importance of endogenous normative aspects and how these shape national responses to global processes, yet applied to the German case, see Schirm 2002.

15 This commission is an initiative of President Michelle Bachelet to discuss ways to design better policies to create more equity in the labor market as well as a social pact for the development of Chile. 
asks whether private companies are essential to the development of a country, and the answers in the Chilean case support such a claim: 61 percent in 2004, 45 percent in 2005 and 58 percent in 2007. Moreover, the level of support for the claim that "The market economy is the only pattern with which the country can achieve development" is relatively high, though the numbers for this claim have decreased in the last two years. However, the support for the statement "The state can solve all problems," that is, economic and social ones, does not surpass the preference for a market economy and has also not increased substantially in recent years (see Table 2).

\section{Table 2: The State vis-à-vis the Market}

\begin{tabular}{|}
\begin{tabular}{|c|c|c|c|c|}
\hline "The state can solve all problems." \\
\hline $\mathbf{1 9 9 8}$ & $\mathbf{2 0 0 0}$ & $\mathbf{2 0 0 3}$ & $\mathbf{2 0 0 5}$ & $\mathbf{2 0 0 7}$ \\
\hline $31 \%$ & $26 \%$ & $29 \%$ & $33 \%$ & $39 \%$ \\
\hline "The market economy is the only pattern with which the country can achieve development." \\
\hline $\mathbf{2 0 0 3}$ & $\mathbf{2 0 0 4}$ & $\mathbf{2 0 0 5}$ & $\mathbf{2 0 0 7}$ & $\mathbf{2 0 0 8}$ \\
\hline $52 \%$ & $53 \%$ & $62 \%$ & $41 \%$ & $49 \%$ \\
\hline
\end{tabular}
\end{tabular}

Sources: Latinobarometro reports 2007: 30 \& 32; 2008: 35.

Despite the fact that the illustrative numbers of the different surveys presented above are not conclusive enough, they tentatively suggest that the way society is related as a whole is based on the principled idea of individual responsibility rather than on the idea of collective public solidarity. In addition, the state as the main promoter of economic growth seems to have a secondary role vis-à-vis the market for the socioeconomic system (Navia 2006). Yet this socioeconomic transformation was conducted in a top-down way in an authoritarian context (Pinochet's regime) (Huneeus 2001, Moulian 1997). However, the democratic governments from the 1990 onwards have validated and learned to administer the economic model. In fact, there has not been much variation in the market-driven economic policy during the last four democratic governments, all of which have been center-left coalitions ( $L a$ Concertación) (Fazio 2006; Navia 2006).

Although each democratic government has placed a strong emphasis on social policies to reduce poverty and even on "leveling the playing field" for everyone, the overall orientation of the economic model has been preserved (Engel and Navia 2006). In this regard, it seems that the debate focuses on what type of capitalism Chile needs, amongst the different existing varieties, rather than on a radical ideological shift in the model (on varieties of capitalism see Hall and Soskice 2001). While some surveys ask whether or not the model should be changed and more state intervention added (and the answers favor this option), they do not ask which substitute model respondents are thinking of (see Chilean Work and Equity 
Commission 2008: 39). The numbers supporting the principle of self-responsibility and the reasons for economic success suggest that the perceived need for more state involvement is circumscribed to the varieties of capitalism and does not go beyond this.

The above numbers illustrate an extant reality, yet they are not conclusive enough as these surveys might only represent a transitory, specific time setting and thus not show whether there is a sedimentation of the ideational aspect "market as welfare enhancer" in the long run. Therefore, it seems appropriate to analyze the official discourse of representatives of the civil society and the Chilean government to determine whether the leaders and societal movements validate the extant economic pattern.

In her government program, President Michelle Bachelet (2006-2010) highlights the core principle of combining market and equity. “We need to continue walking with security on the path to economic development, based on seriousness and a balanced budget, without stopping the help to those who are left behind and need us" (Bachelet 2005: 2). She refers to the economic model as follows: "This prosperity will open the way to leave poverty behind and substantially increase the quality life of Chileans" (ibid.: 8). "Growth is not achieved through magic. It requires adequate policies. We will preserve our fiscal and financial policies, which have made us the first country in the world in terms of macroeconomic management according to the World Economic Forum ranking" (ibid.: 34). ${ }^{16}$

This societal convergence around the economic model has facilitated the government's proactive FTA policy. As Hector Casanueva, former representative of the Chilean government on external trade issues under the governments of Eduardo Frei and Ricardo Lagos, declared in relation to the wide acceptance within civil society of the economic model and the bilateral economic policy,

It is necessary to highlight that this strategy has a broad base of support in Chilean society. And this is an essential component that allows the continuity and security of this process. There is a national consensus among the different political views within Congress, the private sector, and the labor unions, with some slight differences, as it should be, but no radical or big challenges to the economic model. Other groups of civil society also accept the model despite the normal differences of opinion. Thus, the international presence-economic-in Chile is not an issue in itself; what it is discussed in different sectors or national levels are opportunities, moments, and how this process can be administered in a better way, but not the essence of this policy in itself. (Casanueva 2001: 32) ${ }^{17}$

Another survey shows 73.9 percent support for Chile's FTA policy as a whole; only 6.4 percent of those surveyed were against it (IDEP November 2002: 2). An interesting example is

16 Author's translation. 
the FTA negotiation with the US, which is perhaps the actor that generates the most controversy and divergence, amongst elites as well as in civil society in general, on the Latin American continent. When the FTA negotiation between Chile and the US was launched, the level of support for it was 81 percent (Fundación Futuro 2000: 12). Support for this negotiation and for the external trade policy in general is also present amongst groups that were traditionally and ideologically against a free-market approach, such as the labor unions. As the then advisor on commercial matters of the largest labor union in Chile, the Central Unitaria de Trabajadores (CUT), Alfredo Arrieta (2001: 69) said,

The Chilean workers' union movement supports the negotiations the government is conducting, not only with the US but also with Mercosur, APEC, and the EU [...] The Chilean workers consider this to be a unique opportunity for the country because until now the model has been exclusive and this may become a good chance to convert it into a model of development and integrative growth. ${ }^{18}$

While the cemented value-based idea of "market as welfare enhancer" facilitates the implementation of Chile's external trade policy in a consensual way by economic and political elites, it does not provide a contextual understanding of Chile's willingness to share its negotiating experience with potential economic competitors, nor its invitations to and support for other Latin American countries joining extant economic forums and FTAs. Chile supported and promoted Peru's entrance to APEC, and it currently supports the memberships of Colombia, Panama, and Ecuador whenever APEC opens new application processes. Chile has invited Peru to be part of the P4 (Furche 2008) and it also expects that Colombia will join in the near future (Americas Society and Council of the Americas 2006, Estrada 2006, El Colombiano 28/11/ 2006). According to trade diplomats from Chile (Andrés Rebolledo 25/03/2008) and Costa Rica (Laura Rodriguez 08/07/2008, Gabriela Llobet 02/07/2008) and Chile's former minister of foreign affairs, Soledad Alvear (see Verdugo 2005: 146), Chile is always willing to share its past FTA negotiating experiences with other Latin American countries. This extends to sharing the details of the timing and the amount of initial offers regarding specific products given by counterparts, for example, the US (anonymous interview 04/07/2008). This seems illogical according to a cost-benefit analysis since these countries may get a better deal if they manage the momentum of the negotiations over sensitive products. This may also give them privileged access to the US market due to their lower transportation costs.

Considering that Chile feels unique and far removed from the reality of other Latin American countries, it is puzzling to observe this phenomenon of it sharing its negotiation experience and inviting countries to join already established commercial accords. Chileans perceive themselves as different from the rest of the Latin Americans (57 percent), and they 
tend to think that there is no such thing as a Latino culture on the continent (75 percent) (Adimark-PUC 2008: 39-40, 43-44, 48). A plausible explanation for this Chilean openness to sharing with and inviting other countries lies precisely in this self-constructed uniqueness and in the criticisms Chile has received from other countries for not paying too much attention to the Latin American continent in its external relations.

Jorge Larrain (2005: 7-15) persuasively argues that this uniqueness is an identity project conducted in a top-down way that hides the cultural and identitarian heterogeneity of a nation. Therefore, this uniqueness is only one version of the Chilean identity. Whereas Larrain's argument identifies other identity aspects, I argue that the one which prevails in Chile's external economic relations is that of differentiation from the rest of Latin America. Moreover, it seems to be the case that a majority of Chilean society agrees with this dialectical differentiation. Yet identity is not only about the past and the present, that is, what a country is, but also about the future projection of what a country wants to be.

Whereas Chilean society perceives itself as different, the political elite expect to change this self-perception of not belonging to the rest of Latin America (Miranda 23/10/2004). In this regard, the articulation of narratives and discourses of self-identification with other countries that share similar notions of valued-based ideas on the path of development may be a first step towards constructing more ideational convergence. As then president Ricardo Lagos (21/05/2005) stated in 2005, “We have said over and over again that Latin America is our big nation and that we make our foreign policy from this region." ${ }^{19}$ Discursive commitments and meaningful actions towards helping, sharing, and supporting the economic integration of other countries by inviting them to join extant trade accords might be used as a framing mechanism to create self-identification with others. The construction of this self-identification serves as an identity mark for developing a greater sense of belonging to Latin America. However, this identity mark is far from being cemented in Chile as it competes with existing value-based ideas of uniqueness or differentiation.

Therefore, helping potentially like-minded Latin American countries may enhance both the developmental pattern of Chile and that of its potential partners. These potentially likeminded countries share the ideational aspect that an open economy improves the life standards of citizens and achieves sustainable economic growth. As they are in the earlier stages of implementing a market-driven economic model, ideational understandings based on the market as welfare-creating are not yet solid enough. Chile thus sees its own economic experience as valuable and shareable. In this regard, the market as a valued-based idea acts as the core driving force in creating potential "selves" on a continent where there are large divergences in the patterns of economic development. 
It would be naïve to think that a public statement from government representatives outlining societal ideas does not have the hidden agenda of realizing and promoting material interests. With regard to open sharing and inviting others to join extant commercial projects, the intention may be to balance the interventionist economic projects promoted by countries such as Venezuela, Bolivia, and Argentina. It could also be a way to improve Chile's always controversial relations with Peru. Yet it is no less true that the manner and intensity of promoting these material interests, such as the incentive of more jobs and more goods as well as the ability of market-driven countries to compete in a better way in the global economic world, are also facilitated by Chile's societal convergence on the idea of the "market as welfare enhancer." The latter ideational dimension is thus used in Chile's foreign policy as an identity mark that enhances the country's own developmental path and that of potentially likeminded countries on the Latin American continent (see Summary in Table 3).

Table 3: Summary of Power, Governance, and Ideational Forces in Chile's FTA Policy

\begin{tabular}{|l|l|}
\hline Instruments & \multicolumn{1}{|c|}{ Goals } \\
\hline Power & $\begin{array}{l}\text { - Soft balancing other integration schemes in the region } \\
\text { - Reducing dependence on global hubs } \\
\end{array}$ \\
\hline - Increasing the country's status
\end{tabular}

Source: Author's compilation.

\section{Conclusion}

This article has addressed both the strategic goals, expressed in terms of power goals and the need for closer mechanisms of governance than those available at the multilateral level, and the ideational aspects of Chile's FTA policy. These political-economic strategic goals and ideational aspects are not as apparent in the short term as the pure economic rationale for pursuing FTAs. However, the pursuit of power and the need for governance institutions and norms do not contradict the utility-maximizing economic logic as they provide for a better understanding of the reasons for negotiating with a diverse array of countries or regions 
with which the volume of trade ranges from extremely low, as is the case with Vietnam, to extremely high, as is the case with China, the EU, and the US.

Chile's FTA policy can be explained by the country's power distribution and its relative power position in the global and regional systems; by its need as a small country in economic affairs to follow and improve the extant mechanisms to manage the economic world by bringing and adapting these rules to its economic and political context; and by the influence of a societal understanding around ideational aspects that provide the context in which this FTA policy is proactively pursued and implemented. In addition, Chile's self-perceived divergence from Latin American countries in economic affairs and cultural issues causes government representatives to try to shift this self-conception through concrete and meaningful actions such as inviting potentially like-minded Latin American countries to join extant commercial accords and sharing its vast negotiating experience. None of these three forcespower, governance, and ideas-can be evaluated separately. While power-based goals and the need to manage economic issues through institutional settings are evident (power and institutions), Chile's extreme proactivity in negotiating FTAs with most countries within the economically interdependent world cannot be understood without the contextual framework provided by a valued-based ideas approach. Therefore, power, governance, and ideas are also constitutive forces that drive Chile to pursue such a proactive FTA policy. 


\section{Bibliography}

Adimark PUC (Pontificia Universidad Católica de Chile) (2008) Encuesta Nacional Bicentenario, November, in: www.adimark.cl/estudios/bic2008.act (accessed on November 17, 2008).

Americas Society and Council of the Americas (2006) Latin America-Asia Trade Agreement Review, July, www.as-coa.org/Newsletter/July/LAC-Asia-Trade-Final.pdf (accessed on April 28, 2008).

Arrieta, A. (2001) Aportes del Seminario Acuerdo de Libre Commercio Chile-EEUU: Las Preguntas desde el desarrollo sustentable, in: Ambiente y Desarrollo, Vol. XVII, No. 4, 59-67.

Bachelet, M. (2005) Programa de Gobierno, October 18, in: www.lanacion.cl/prontus_noticias/ site/artic/20051018/pags/20051018162635.html (accessed November 19, 2008).

Baldwin, R. (2006) Multilateralising Regionalism: Spaghetti Bowls as Building Blocs on the Path to Global Free Trade, in: The World Economy, 29 (11), 1451-1518.

Casanueva, H. (2001) Chile: Apertura y Diversificación, in: Casanueva, Héctor et al. Chile en el Mundo. La Experiencia Chilena de Inserción Internacional e Integración Regional. Santiago: Universidad del Pacifico and Chilean Government.

CEP (Centro de Estudios Públicos) (2008) Estudio Nacional sobre Partidos Políticos y Sistema Electoral, March-April, in: www.cepchile.cl/dms/lang_1/doc_4105.html (accessed on November 12, 2008).

Chilean Work and Equity Commission (2008) Encuesta: Percepciones sobre Relaciones Laborales y Equidad en Chile. Santiago: Presidency of Chile, August, www.trabajoyequidad. cl/view/index.asp (accessed on November 12, 2008).

Corning, G. (2007) Japan's Bilateral FTAs: No Obstacles to Progress in the Doha Round, in: East Asia, 24, 45-67.

DIRECON-Dirección de Relaciones Económicas Internacionales (2008) Informe: Comercio Exterior de Chile. Cuarto Trimestre 2007. Santiago: Gobierno de Chile.

El Colombiano (2006) El TLC con Chile abrirá la puerta para ingreso a Apec, November 28, in: www.elcolombiano.com.co/BancoConocimiento/E/el_tlc_con_chile_abrira_la_puerta_ para_ingreso_a_apec/el_tlc_con_chile_abrira_la_puerta_para_ingreso_a_apec.asp (accessed on May 27, 2008).

Engel, E. and Navia, P. (2006) Que Gane "El Más Mejor". Mérito y Competencia en el Chile de Hoy. Santiago: Arena Abierta.

Estrada, D. (2006) A Bridge between Asia and South America, Interpress Service News Agency, August 24, in: www.bilaterals.org/article-print.php3?id_article=5675 (accessed on May 28, 2008).

Fazio, H. (2006) Lagos: El Presidente “progresista” de la Concertación. Santiago: LOM Ediciones. 
Fortmann, M. / Paul, T.V./Wirtz, J. (2004) Conclusions: balance of power at the turn of the new century, in: Wirtz, J./Paul, T.V./Fortmann, M. (eds.) Balance of Power: Theory and Practice in the 21st Century. Standford: Standford University Press, 360-374.

Fundación Futuro (2000) El Pulso de la Política, December, in: www.fundacionfuturo.cl/ (on request).

Fuentes, C. (2006) La apuesta por el "poder blando": política exterior de la Concertación, in: Funk, Robert (ed.) El Gobierno de Ricardo Lagos. Santiago: Diego Portales University Press, 105-122.

Furche, C. (2008) Oportunidades en Tiempos difíciles, in: La Tercera, November 21, 4.

Gartzke, E./Li, Q./Boehemer, Ch. (2001) Investing in the peace: Economic interdependence and international conflict, in: International Organization, Vol. 55, No. 2, 391-438.

Gerber, J. (2000) Cruzando fronteras: políticas nacionales y los límites de la integración internacional, en: Gerber et al. Inserción Económica Internacional de América Latina. Santiago: Flacso-Chile, 31-62.

Gilpin, R. (2001) The Global Political Economy: Understanding the International Economic Order. Princeton and Oxford: Princeton University Press.

Gilpin, R. (1987) The Political Economy of International Relations. Princeton: Princeton University Press.

Goldstein, J./Keohane, R. (eds.) (1993) Ideas and Foreign Policy: Beliefs, Institutions and Political Change. Ithaca NY: Cornell University Press.

Grieco, J. (1990) Cooperation Among Nations: Europe, America, and Non-tariff Barriers to Trade, Ithaca: Cornell University Press.

Hall, P. and Soskice, D. (2001) An introduction to varieties of capitalism, in: Hall, P./Soskice, D. (eds.) Varieties of Capitalism. The Institutional Foundations of Comparative Advantage, Oxford: Oxford University Press, 1-68.

He, K. (2008) Institutional balancing and international relations theory: economic interdependence and balance of power strategies in Southeast Asia, in: European Journal of International Relations, Vo. 14, No. 3, 489-518.

Huneeus, C. (2001) El Régimen de Pinochet. Santiago: Sudamericana.

IDEP (Instituto de Estudios Políticos), Universidad Andrés Bello (2002) Creencias y Actitudes Democráticas de los Chilenos, November, in: www.fundacionfuturo.cl/ (on request).

Katzenstein, P./Rudra, S (2004) Rethinking Asian Security. A Case for Analytical Eclecticism, in: Suh, J.J. / Katzenstein, P. / Carlson, A. (eds.) Rethinking Security in East Asia. Identity, Power, and Efficiency. Stanford: Stanford University Press, 1-33.

Keohane, R. (2005) After Hegemony: Cooperation and Discord in the World Political Economy. Princeton: Princeton University Press. 
Larrain, J. (2005) Integración regional e identidad nacional: Chile, ¿país modelo?, in: Revista del Sur, No. 161, July-September, 7-15.

Lagos, R. (2005) Mensaje Presidencial del 21 de Mayo. May 21, Valparaiso, in: www.fundacion democraciaydesarrollo.cl/memoria/view/view-DiscursoEntrevista.asp?id=202647\# (accessed on November 25, 2008).

La Nación (2003) Alvear firma el pacto commercial más 'soñado' del gobierno de Lagos, in: La Nación, June 6.

Loewen, H. (2006) Towards a dynamic model of the interplay between international institutions, Working Paper, No. 17. Hamburg: German Institute of Global and Area Studies.

López Giral, D. (2006) La apertura comercial de Chile y México: un análisis comparado, in: Comercio Exterior, Vol. 56, No. 8, 703-718.

March, J./Olsen, J. (1998) The institutional dynamics of international political orders, in: International Organization, 52, 943-969.

McDonald, P. (2004) Peace through trade or free trade?, in: Journal of Conflict Resolution, Vol. 48, No. 4, August, 547-572.

Miranda, C. (2004) La misión vecinal del canciller Walker, in: La Nacion.cl, October 23, in: www.lanacion.cl/p4_lanacion/site/artic/20041023/pags/20041023000959.html (accessed on November 25, 2008).

Morandé, J. (2003) Chile: The invisible hand and contemporary foreign policy, in: Mora, F./ Hey, J. (eds.) Latin American and Caribbean Foreign Policy. Oxford: Rowman \& Littlefield Publishers, Inc., 243-264.

Moulian, T. (1997) Chile Actual: Anatomía de un Mito. Santiago: LOM ediciones.

Navia, P. (2006) Chile: Erfolgsmodell des linken Liberalismus, in: Nueva Sociedad, Special Issue, $44-53$.

Nye, J. (2007) Notes for a soft power research agenda, in: Berenskoetter, F. / Williams, M.J. (eds.) Power in World Politics. Oxford and New York: Routledge, 162-172.

Olivares, E. (2008) Cancillería Trabaja en Nuevos TLC al cierre del Gobierno de Bachelet: Rusia y Golfo Persico, in: El Mercurio, October 20, www.economiaynegocios.cl/noticias/ noticias.asp?id=54882 (accessed on November 15, 2008).

Oneal, J. (1999) "Assessing the liberal peace with alternative specifications: Trade still reduces conflict", in: Journal of Peace Research, Vol. 36, No. 4, 423-432.

Payne, R. (2001) "Persuasion, frames and norm construction", in: European Journal of International Relations, Vol. 7, No. 1, 37-61.

Portilla, R. (2006) Mercosur: Chile en la encrucijada, in: Crónica Digital, July 24, www.cronica digital.cl/modules.php?name=News\&file=print\&sid=4671 (accessed on July 4, 2008). 
Reiter, J. (2006) International investments rules, in: Woolcock, S. (ed.) Trade and Investment Rule-Making: The Role of Regional and Bilateral Agreements. Tokyo/New York/Paris: United Nations University Press, 208-240.

Rosales, O. (2008) Integración regional: Propuestas de renovación, in: Altmann, J./Rojas, F. (eds.) Las paradojas de la integración en América Latina y el Caribe. Madrid: Fundación Carolina y Siglo XXI, 33-66.

Rose, G. (1998) Neoclassical realism and theories of foreign policy, in: World Politics, Vol. 51, No. 1, 144-172.

Sáez, S. / Valdés, J.G. (1999) Chile and its "Lateral” Trade Policy, in: Cepal Review, No. 67, 85-131.

Sauvé, P. (2006) Trade and investment rules: Latin American perspectives, Serie Comercio Internacional 66, April. Santiago: Economic Commission for Latin America and the Caribbean.

Schirm, S. (2008) Domestic Ideas and Interests in Global Governance: Comparing German and U.S. Preference Formation. Part 2 of the Germany in Global Economic Governance Series. Working Paper 2. Mario Einaudi Center for International Studies, Cornell University.

Schirm, S. (2004) The divergence of global economic governance strategies, in: Schirm, S. (ed.) New Rules for Global Markets. Public and Private Governance in the World Economy. New York/Houndmills: Palgrave Macmillan, 3-21.

Schirm, S. (2002) The power of institutions and norms in shaping national answers to globalization: German economic policy since unification, in: German Politics, Vol. 11, No. 3, 217-237.

Silva, V. (2001) Estrategia y agenda commercial chilena en los años noventa, Serie Comercio Internacional 11, June. Santiago: Economic Commission for Latin America and the Caribbean.

Smith, P. (2001) Strategic Options for Latin America, in: Tulchin, J./ Espach, R. (eds.) Latin America in the International System. Boulder: Lynne Rienner Publishers, 35-72.

Solís, M. / Katada, S. (2008) Understanding East Asian cross-regionalism: an analytical framework, in: Pacific Affairs, Vol. 80, No. 2, 229-257.

Ulloa Urrutia, A. (2003) Chile's Trade Policy and the Chile-United States Free Trade Agreement, Cuba in Transition: Volume 13. Papers and Proceedings of the Thirteenth Annual Meeting of the Association for the Study of the Cuban Economy (ASCE), Coral Gables, Florida, August 7-9.

Valdivieso, P. (2007) A Propósito de las Relaciones Chile-Bolivia-Perú: Percepciones, Experiencias y Propuestas, Bicentenario, in: Revista de Historia de Chile y América, Vol. 6, No. 2, 99-123.

Verdugo, P. (2005) Alvear: revelaciones de una mujer de Estado. Santiago: Catalonia.

Viner, J. (1950) The Customs Union Issue. New York: Carnie Endowment for International Peace. 
Waltz, K. (1979) Theory of International Relations. New York: McGraw-Hill; Reading: Addison-Wesley.

Wesley, M. (2008) The strategic effects of preferential trade agreements, in: Australian Journal of International Affairs, Vol. 62, No. 2, 214-228.

Wonnacott, R. (1996) Trade and investment in hub and spoke system vs. a free trade area, in: World Economy, Vol. 19, No. 3, 237-252.

Woolcock, S. (2006) Introduction: The interaction between levels of rule-making in international trade and investment, in: Woolcock, S. (ed.) Trade and Investment Rule-Making: The Role of Regional and Bilateral Agreements. Tokyo/New York/Paris: United Nations University Press, 1-26.

Zechner, C. (2002) Expanding NAFTA. Economics effects on Chile of free trade with the US. Berlin/Hamburg/Münster: LIT Verlag.

\section{Official Texts of Chile's FTAs}

DIRECON (Dirección General de Relaciones Económicas Internacionales) (2008) Free Trade Agreement texts, in: www.direcon.cl.

Chile-Costa Rica's Bilateral Investment Treaty (signed on July 11, 1996), in: www.direcon.cl (accessed on May 26, 2008).

Chile-El Salvador's Bilateral Investment Treaty (signed on November 8, 1996), in: www. direcon.cl (accessed on November 10, 2008).

Chile-European Community Association Agreement Text (2002), in: www.direcon.cl (accessed on November 3, 2008).

Chile-Panama's Bilateral Investment Treaty (signed on November 8, 1996), in: www.direcon. cl (accessed on November 10, 2008).

FTA Chile-Canada (1996), in: www.direcon.cl (accessed on March 13, 2008).

FTA Chile-Central America (1999), in: www.direcon.cl (accessed on May 15, 2007).

FTA Chile-Japan (2007), in: www.direcon.cl (accessed on September 12, 2008).

FTA Chile-Mexico (1998), in: www.direcon.cl (accessed on May 27, 2008).

FTA Chile-Panama (2006), in: www.direcon.cl (accessed on April 2, 2008).

FTA Chile-South Korea (2003), in: www.direcon.cl (accessed on July 30, 2008).

FTA Chile-US (2003), in: www.direcon.cl (accessed on August 7, 2008).

Trans-Pacific SEP Agreement among Chile, New Zealand, Singapore and Brunei Darussalam (2002), in: www.direcon.cl (accessed on November 13, 2008). 


\section{Interviews}

Anonymous (July 4, 2008), former trade diplomat, Costa Rica.

Llobet, Gabriela (July 02, 2008), former trade diplomat at the Ministry of International Trade, Costa Rica.

Rebolledo, Andrés (March 25, 2008), head of bilateral trade negotiatons, DIRECON office at the Ministry of foreign affairs, Chile.

Rodriguez, Laura (July 8, 2008), trade diplomat at the Ministry of International Trade, Costa Rica. 


\section{GIGA Journal Family}

The GIGA journal family is a unique publishing initiative that brings together five international area journals edited by the GIGA German Institute of Global and Area Studies.

The journals are high-standard venues for original research on and empirically sound analysis of contemporary politics, society and the economy in Africa, China, Latin America, the Middle East, and Southeast Asia.

- Africa Spectrum

(3 issues per year)

- Journal of Current Chinese Affairs - China aktuell

(4 issues per year)

- Journal of Current Southeast Asian Affairs

(4 issues per year)

- JPLA - Journal of Politics in Latin America

( 3 issues per year)

As of 2009 the full content of the GIGA journals is available at www.giga-journal-family.org.

GIGA German Institute of Global and Area Studies

Leibniz-Institut für Globale und Regionale Studien

Neuer Jungfernstieg 21 - 20354 Hamburg - Germany

Phone: +49 40 42825-594 - Fax: +49 40 42825-547

E-mail: info@giga-hamburg.de

Homepage: www.giga-hamburg.de

Ask for your personal sample copy.

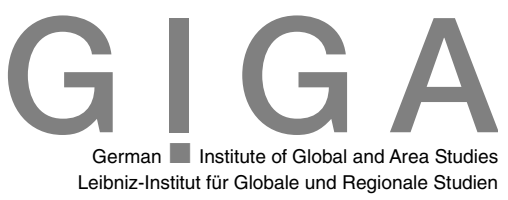




\section{G

\section{Recent Issues}

No 101 Sebastian Huhn: Contested Cornerstones of Nonviolent National Self-Perception in Costa Rica: A Historical Approach; May 2009

No 100 Matthias Basedau, Alexander Stroh: Ethnicity and Party Systems in Francophone SubSaharan Africa; May 2009

No 99 Christian von Soest: Stagnation of a "Miracle": Botswana's Governance Record Revisited; April 2009

No 98 Melanie Hanif: Indian Involvement in Afghanistan: Stepping Stone or Stumbling Block to Regional Hegemony?; April 2009

No 97 Annette Büchs: The Resilience of Authoritarian Rule in Syria under Hafez and Bashar AlAsad; March 2009

No 96 Alexander Stroh: The Power of Proximity: Strategic Decisions in African Party Politics; February 2009

No 95 Robert Kappel, Juliane Brach: Handel, Hierarchien und Kooperation in der Globalisierung; February 2009

No 94 Mirko Bendig, Lena Giesbert, Susan Steiner: Savings, Credit, and Insurance: Household Demand for Formal Financial Services in Rural Ghana; January 2009

No 93 Leslie Wehner: Más allá de lo económico: Los objetivos estratégicos de los TLCs de Chile y México; January 2009

No 92 Howard Loewen: Democracy and Human Rights in the European-Asian Dialogue: A Clash of Cooperation Cultures?; December 2008

No 91 Bert Hoffmann: Bringing Hirschman Back In: Conceptualizing Transnational Migration as a Reconfiguration of "Exit", "Voice", and "Loyalty"; December 2008

No 90 Ulrich Mückenberger: Civilising Globalism: Transnational Norm-Building Networks A Research Programme; October 2008

No 89 Martin Beck: Regional Politics in a Highly Fragmented Region: Israel's Middle East Policies; September 2008

No 88 Nadine Godehardt: The Chinese Meaning of Just War and Its Impact on the Foreign Policy of the People's Republic of China; September 2008

No 87 Andreas Mehler: Breaking the "Insecurity Trap"? How Violence and Counter-violence Are Perpetuated in Elite Power Struggles; September 2008

All GIGA Working Papers are available free of charge at www.giga-hamburg.de/workingpapers. For any requests please contact: workingpapers@giga-hamburg.de.

Editor of the Working Paper Series: Martin Beck 